\title{
Deer and Elk Use on Foothill Rangelands in Northeastern Oregon
}

\author{
RICHARD F. MILLER, WILLIAM C. KRUEGER, AND MARTIN VAVRA
}

\section{Abstract}

Forested foothills of the Wallowa Mountains in northeastern Oregon provide spring and early summer range for deer and elk. Deer and elk use varied both between plant communities and seasonally within plant communities. Plant species composition of big game diets also varied with season. Bunchgrass and logged communities collectively occupying $57 \%$ of the land area studied, provided $90 \%$ of the big game diet during spring and early summer. Grasses made up $52 \%$ of the diet, forbs $38 \%$, and browse $10 \%$. Timothy and western goatsbeard were the two most important species consumed by big game. Pellet groups did not reliably estimate the value of various communities to deer and elk for forage use.

Forested foothills of the Wallowa Mountains in northeastern Oregon provide habitat for mule deer (Odocoileus hemionus hemionus) and Rocky Mountain elk (Cervus canadensis nelsonii) during the winter, spring, and early summer. This area also provides an important source of timber, water, fish, recreation, and summer forage for livestock. Through assessing the value of plant communities and the impact of logging practices for deer and elk, land managers can deal more effectively with the competitive relationship between big game and other land uses.

Objectives of this study were to: (1) determine the importance of various plant species in the diet of deer and elk; (2) evaluate deer and elk preferences for different plant communities including forested communities that have been clearcut and seeded to forage plants, and (3) evaluate differences and/or similarities between forage utilization and pellet group densities to estimate the value of various plant communities for deer and elk forage.

\section{Study Area}

The study area was located in the foothills of the Wallowa Mountains in northeastern Oregon at the Eastern Oregon Agricultural Research Center, Union Branch. Elevation ranges from 1,006 to $1,219 \mathrm{~m}$. Habitat types identified in the study area were ponderosa pine-bluebunch wheatgrass (Pinus ponderosa-Agropyron spicatum); ponderosa pine-snowberry (Pinus ponderosaSymphoricarpos albus); Douglas fir-snowberry (Pseudotsuga menziesii-Symphoricarpos albus) Douglas fir-ninebark (Pseudotsuga menziesii-Physocarpus malvaceus); and grand fir-pachistima (Abies grandis-Pachistima myrsinites) as determined from the keys in Daubenmire (1970) and Daubenmire and Daubenmire (1968). The grand fir-pachistima habitat type was represented by a grand fir-adenocaulon (Abies grandis-Adenocaulon bicolor) community. A Sandberg bluegrass-Kellogg onion (Poa sandbergii-Allium anceps) community was also important in the study area but it did not reflect any previously identified habitat type. These habitat types correspond with Hall's (1973) plant community types as

At the time of the research, authors were, assistant professor, associate professor, Rangeland Resources Program, Department of Animal Science, Oregon State University, Corvallis, and associate professor, Eastern Oregon Agricultural Research Center, Union, respectively. Dr. Krueger is currently chairman, Range Science Department, Univeristy of Colorado, Fort Collins.

This report was submitted as Technical Paper No. 5254. Oregon Agricultural Experiment Station, Corvallis.

Manuscript received August 27, 1979. follows: ponderosa pine-bluebunch wheatgrass with ponderosa pine-wheatgrass; ponderosa pine-snowberry with ponderosa pineDouglas fir-snowberry-oceanspray (Holodiscus discolor); Douglas fir-snowberry and Douglas fir-ninebark with ponderosa pine-Douglas fir-ninebark; grand fir-pachistima with white firtwinflower-forb (Abies concolor-Linnaea borealis); and Sandberg bluegrass-Kellogg onion with bluegrass scabland. Although both Douglas fir habitat types fall within Hall's ponderosa pineDouglas fir-ninebark community type, the Douglas fir-snowberry habitat type was located on a west aspect while the more mesic Douglas fir-nincbark habitat type was on a northwest aspect.

Understory production in the bunchgrass communities, Sandberg bluegrass-Kellogg onion and ponderosa pine-bluebunch wheatgrass, averaged 343 kilograms per hectare (Table 1); and tree canopy cover was $4 \%$ or less (Miller and Krueger 1976). Understory production in the three forested communities, ponderosa pine-snowberry, Douglas fir-snowberry, and grand firadenocaulon varied from 69 to 138 kilograms per hectare. Tree canopy cover ranged from 55 to $91 \%$ for these forested communities. Also contained within the study area was a 27 -hectare forest clearcut. The area was logged in 1969, burned in July 1970, and seeded in September 1970 to timothy (Phleum pratense), tall oatgrass (Arrhenatherum elatius), white Dutch clover (Trifolium repens), Manchar smooth brome (Bromus inermis), orchardgrass (Dactylis glomerata), and blue wildrye (Elymus glaucus). Habitat types contained within the logged area included ponderosa pinesnowberry, Douglas fir-ninebark, and grand fir-pachistima. Plant communities established in the clearcut were: Kentucky bluegrassgoatsbeared (Poa pratensis-Tragopogon dubius) in the ponderosa pine-snowberry habitat type; ninebark-timothy in the Douglas fir-ninebark habitat type; and timothy-orchardgrass in the grand fir-pachistima habitat type. Understory production ranged from 564 to 622 kilograms per hectare during the study period (Table 1). Miller and Krueger (1976) give a more detailed description of these communities.

\section{Methods}

Herbage and browse production, forage utilization and pellet

Table 1. Percent composition by community, total production, and percent of spring and early summer diet of big game from each stand on the study area (March - July 1973).

\begin{tabular}{|c|c|c|c|c|c|c|}
\hline COMMUNITIES & \begin{tabular}{|c|} 
PERCENT \\
COMMUNITY \\
COMPOSITION
\end{tabular} & $\begin{array}{l}\text { TOTAL } \\
\text { PROOUCTION } \\
\mathrm{kg} / \mathrm{ho}\end{array}$ & $\begin{array}{r} \\
\text { GRASSES } \\
\end{array}$ & $\begin{array}{l}\text { ERCENT } \\
\text { DIET } \\
\text { FOROS }\end{array}$ & TBROWSE & TOTAL \\
\hline \multicolumn{7}{|l|}{ BUNCHGRASS } \\
\hline$\overline{\text { Sondberg bluegrass-Kellogg onion }}$ & 8 & 345 & 3 & 4 & 0 & 7 \\
\hline Ponderosa pine-bluebunch wheatgrass & 18 & 342 & 16 & 1 & 0 & 17 \\
\hline \multicolumn{7}{|l|}{ FOREST } \\
\hline Ponderoso pine - snowberry & 14 & 138 & $t$ & 3 & $\mathrm{t}$ & 3 \\
\hline Douglas fir - snowberry & 24 & 135 & 3 & 0 & 1 & 4 \\
\hline Grand fir-odenocaulon & 3 & 69 & 1 & 2 & $t$ & 3 \\
\hline \multicolumn{7}{|l|}{ CLEARCUT FOREST } \\
\hline Kentucky bluegross - goatsbeord & 8 & 564 & 3 & 25 & 3 & 31 \\
\hline Ninebark - timothy & 10 & 620 & 2 & I & 4 & 7 \\
\hline Timothy-orchardgrass & 13 & 622 & 24 & 2 & 2 & 28 \\
\hline TOTAL & $98^{\prime}$ & & 52 & 38 & 10 & \\
\hline
\end{tabular}

1 The additional $2 \%$ is lost to rounding error. 
groups were measured in mid-March, mid-May, mid-July, early September and late October. Herbage production was sampled by the weight estimate method (Pechanec and Pickford 1937a) on twenty $0.43-\mathrm{m}^{2}$ circular plots in each community. Plots were randomly distributed throughout each community during each sampling period. The ocular estimate by plot method was used to estimate utilization of herbaceous species in 40 randomly distributed $0.43 \mathrm{~m}^{2}$ circular plots in each community (Pcchanec and Pickford 1937 b). Ten additional plots were protected with wire cages and clipped during each sampling date to correct estimate plots (Wilm et al. 1944). Cages were moved to a new location at the end of each sampling date.

Production and utilization on shrub species less than $45 \mathrm{~cm}$ in height were also measured in the $0.43-\mathrm{m}^{2}$ circular plots. Browse production and utilization for the larger shrubs were measured in eight permanent belt transects $48.8 \mathrm{~m}$ long and $1.3 \mathrm{~m}$ wide in each plant community. These belt transects were randomly distributed throughout plant communities parallel to slope contour. Annual growth was calculated by recording leader length on approximately $25 \%$ of each shrub occurring in the transect. Only unbrowsed leaders were measured. Outside of the permanent transect, a sample of leaders was measured for length, clipped, and dried at $60^{\circ} \mathrm{C}$ for 48 hours for each species. Leader length measurements were then converted to oven dry weight. Percent use of new leader length was estimated for browse species occur ring within the transects. On these same transects pellet groups for deer and elk were counted and cleared (Neff 1968).

Plant species composition of big game diets was calculated from production and utilization measurements. Total herbage and browse produced by species was estimated in each community by multiplying $\mathrm{kg} /$ ha of species produced by number of hectares in that community. Then these production figures were multiplied by percent forage utilization of corresponding plant species within each community. These data were totaled across communities to determine total kilograms of each species consumed by big game in the study area. Preference of deer and elk for each plant species was evaluated with a relative preference index (RPI) (Van Dyne and Heady 1965). This was a ratio between percent composition of a plant in the animals's diet to percent composition of the same plant on the range.

$$
\text { Relative Preference Indes }(\mathrm{RPI})=\frac{\text { Percent Diet }}{\text { Percent composition on range }}
$$

All herbage production, utilization, diet, and composition values were converted to oven dry weight.

Analysis of variance with a completely randomized design and Duncan's new multiple range test were used to test differences (at the $95 \%$ confidence level) of pellet group densities and levels of forage utilization between plant communities. Linear regression was used to test the correlation between number of pellet groups within each community with the amount of forage each contributed to the big game diet. Throughout this paper the term significant refers to $P \leq 0.05$.

\section{Results and Discussion}

Deer and elk use on the study area occurred primarily during the winter, spring and early summer. Deer and elk moved down to the study area as winter snow accumulated on high summer range. Pellet groups and forage utilization increased from winter to spring, peaking in April and mid-May; by June they declined back to winter levels. Overall herbage and browse utilization in the eight communities during spring and early summer ranged from less than 1 to $5 \%$ of total available plant production. Utilization on principal species providing a major part of the dict ranged from 2 to $12 \%$. Use of certain preferred forbs, however, commonly exceeded $40 \%$. From the last week of June until late fall, no measurable forage use or new pellet groups occurred in the study area. At this time most deer and elk had moved back onto high elevation range. A few deer remained on the study area throughout the summer and fall, but utilization was too light to measure.

\section{Deer and Elk Community Preferences}

Big game diets and pellet group distribution varied both between plant communities. The three clearcut communities provided $66 \%$ of the big game diet during the entire foraging season while accounting for $31 \%$ of the land a rea studied (Table 1). The timothyorchardgrass community was the most important source of forage from March until mid-May (Fig. 1). This community provided 41 to $54 \%$ of the big game diet during this period. Contribution of forage to the diet in this community dropped to $10 \%$ in June when forage utilization shifted primarily to the Kentucky bluegrassgoatsbeard and ponderosa pine-bluebunch wheatgrass communities. These communities provided 51 and $33 \%$ (respectively) of the big game diet from mid-May through June. The ninebark-timothy community in the clearcut was also important during March. Forage utilization on this community dropped steadily during March, May, and June. During this time contributions to the diet decreased from 26 to 11 to $3 \%$. The Kentucky bluegrassgoatsbeard community was the only logged community receiving relatively light use from March to mid-May, but became a major source of forage from mid-May through June.

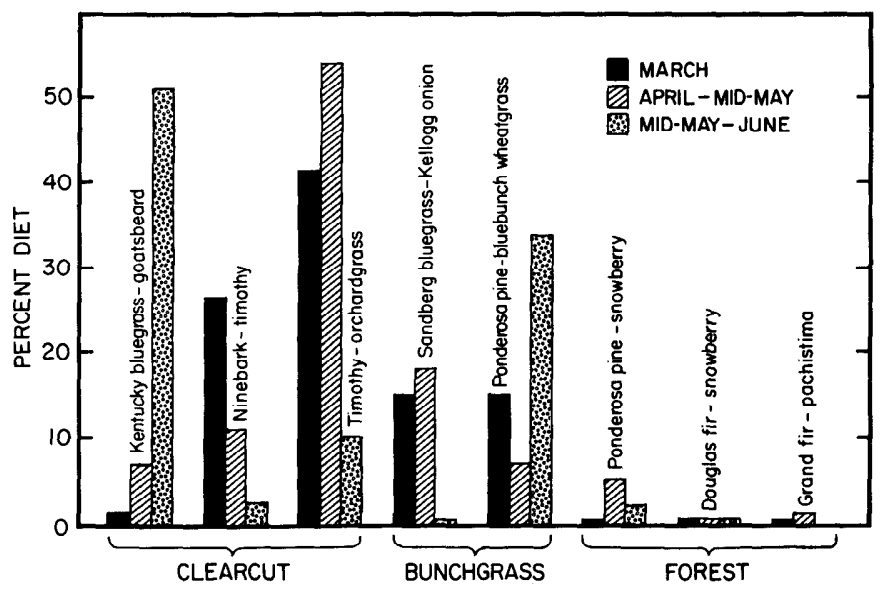

Fig. 1. Percent diet of big game in spring and early summer contributed by each stand on the study area.

Deer and elk pellet groups did not reflect the same importance of the three logged communities as did forage utilization. Based on elk pellet groups, animals did not significantly prefer any of the eight plant communities throughout the study area (Fig. 2). Additionally, levels of elk pellet groups did not correlate with forage utilization. Clearcut communities appeared to be avoided by deer as reflected by pellet group distribution (Fig. 3). Deer pellet groups

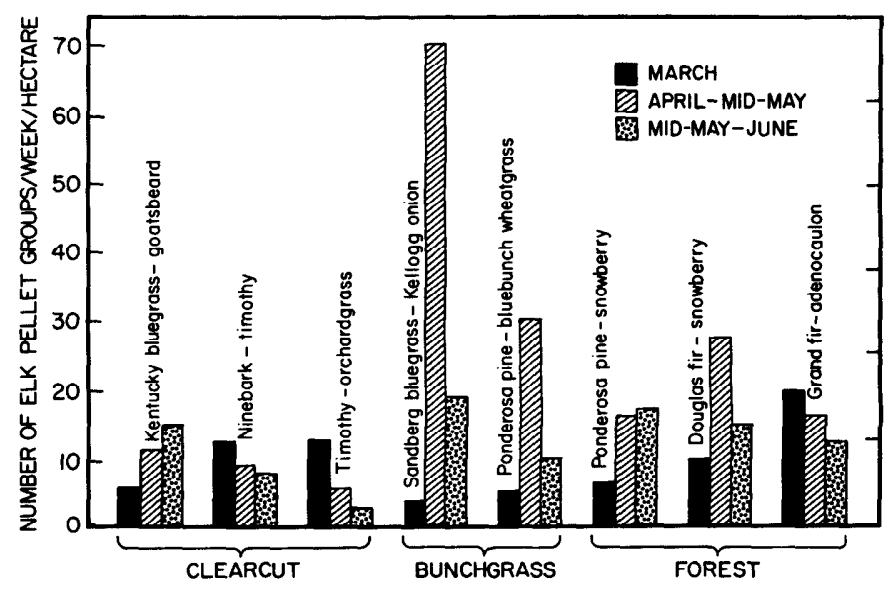

Fig. 2. Elk pellet groups per week per hectare in each stand during winter, spring and early summer on the study area (Sept. 1972-July 1973). 


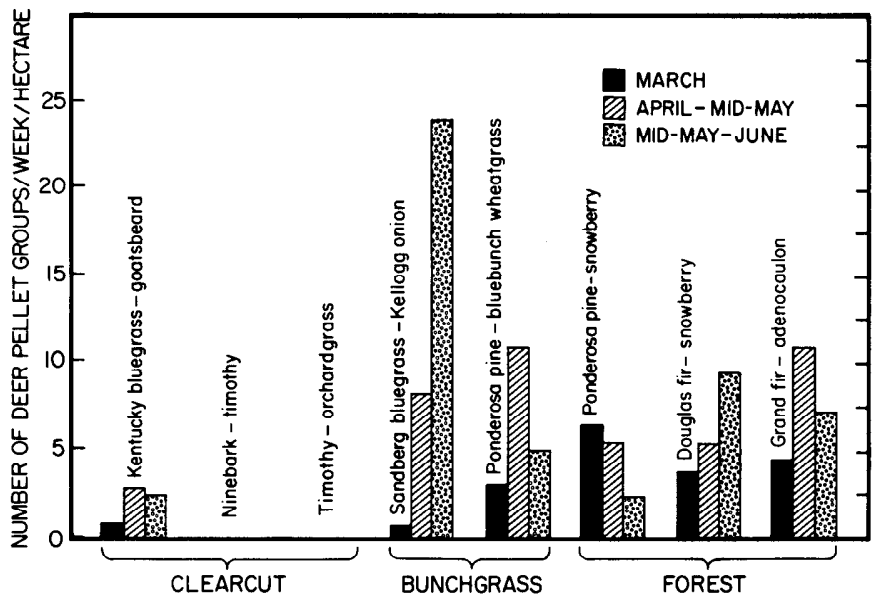

Fig. 3. Deer pellet groups per week per hectare in each stand during winter, spring and early summer on the study area (Sept. 1972-July 1973).

were significantly lower on the ninebark-timothy and timothyorchardgrass communities than on bunchgrass or forest communities throughout the spring and summer. Although deer pellet groups only occurred in the clearcut on the Kentucky bluegrassgoatsbeard community, deer were observed foraging in the timothy-orchardgrass community on several occasions. The entire logged area accounted for only $4 \%$ of the deer pellets in the area studied.

The two bunchgrass communities provided $24 \%$ of the big game diet during March, April, May, and June (Table 1). The Sandberg bluegrass-Kellogg onion community, although occupying only $8 \%$ of the land area, was important for providing both grasses and forbs in March, April, and mid-May. It accounted for $17 \%$ of the big game diet during this period (Fig. 1). This community, with shallow soils and a south aspect, was the first to initiate growth in the spring. However, due to the aridity of the site, plants matured and dried early. No measurable forage use occurred after midMay.

The ponderosa pine-bluebunch wheatgrass community was also an important source of forage for deer and elk during the spring and early summer. This community provided 15,7 , and $33 \%$ of the big game diet on the study a rea in March, May, and June, respectively. From mid-May through mid-June this community was second only to the Kentucky bluegrass-goatsbeard community in forage use.

Relatively low densities of elk pellet groups occurred on both of the above bunchgrass communities during the winter (Fig. 2). However, from March to mid-May the highest pellet group densities in the study area occurred on these two communities. Levels of elk pellet groups decreased in mid-May and June on both communities, which did not reflect forage utilization. Deer pellet group densities significantly increased on the Sandberg bluegrassKellogg onion site from relatively low densities in the winter to the highest density of any community on the study area in June (Fig 3). Seasonal trends of deer pellet group densities on the ponderosa pine-bluebunch wheatgrass site were similar to those of elk pellet group densities, peaking in April and mid-May and declining after mid-May.

Although the three forested communities accounted for $41 \%$ of the area studied, they only provided $10 \%$ of the total big game diet in the spring and early summer (Table 1). However, based on pellet groups, big game preference for these communities appeared to be comparable to other communities (Fig. 2 and 3).

\section{Diet Composition}

Grasses made up 52\% of the big game diet in March, April, May, and June (Table 1) and generally were moderate in preference values (Table 2). The ponderosa pine-bluebunch wheatgrass and timothy-orchardgrass community provided the highest levels of
Table 2. Percent composition of selected plant species in the diet of big game and their relative preference index, RPI (March-July 1973).

\begin{tabular}{|c|c|c|}
\hline Species & Percent diet & RPI \\
\hline \multicolumn{3}{|l|}{ Grasses and sedges } \\
\hline Phleum pratense (seeded) & 18 & 2.4 \\
\hline Arrhenatherum elatus (seeded) & 8 & 2.3 \\
\hline Poa sandbergii & 6 & 1.1 \\
\hline Dactylis glomerata (seeded) & 6 & 0.7 \\
\hline Agropyron spicatum & 3 & 0.8 \\
\hline Elymus glaucus (seeded) & 2 & 1.3 \\
\hline Festuca idahoensis & 2 & 0.6 \\
\hline Bromus inermis (seeded) & 2 & 2.3 \\
\hline Koelerica cristata & 2 & 3.3 \\
\hline Poa pratensis & 1 & 0.1 \\
\hline Carex geyeri & 1 & 0.2 \\
\hline Carex rossii & 1 & 0.6 \\
\hline \multicolumn{3}{|l|}{ Forbs } \\
\hline Tragopogon dubius & 25 & 273.3 \\
\hline Lupinus caudatus & 2 & 6.0 \\
\hline Lactuca serriola & 2 & 35.0 \\
\hline Agoseris grandiflora & 2 & 17.0 \\
\hline Adenocaulon bicolor & 2 & 20.0 \\
\hline Rumex acetocella & 1 & 1.7 \\
\hline Crepis occidentalis & 1 & 80.0 \\
\hline Arnica fulgens & 1 & 8.3 \\
\hline Epilobium paniculatum & 1 & 2.2 \\
\hline Camassia guamash & 1 & 25.0 \\
\hline \multicolumn{3}{|l|}{ Browse } \\
\hline Symphoricarpos albus & 4 & 2.5 \\
\hline Physocarpus malvaceus & 3 & 5.4 \\
\hline Holodiscus discolor & 2 & 11.0 \\
\hline Ceanothus sanguineus & 1 & 4.2 \\
\hline
\end{tabular}

grasses to the big game diet among communities sampled. Seeded grass species accounted for $36 \%$ of the big game diet. Timothy, junegrass (Koeleria cristata), tall oatgrass, and smooth brome were the most palatable grass species, each with an RPI exceeding two (Table 2). Timothy made up $18 \%$ of the dict.

Thirty-eight percent of the diet was made up of forbs. The majority of forbs were consumed from the Kentucky bluegrassgoatsbeard community in the clearcut. Goatsbeard, the most preferred forb, made up $25 \%$ of the diet. Most forbs consumed by deer and elk were very palatable, having relative preference indexes exceeding two.

Browse accounted for $10 \%$ of the diet although it only made up $5 \%$ of the understory production. Ninebark, oceanspray, redstem ceanothus (Ceanothus sanguineus), and snowberry had preference ratings. Significantly more browse was utilized by deer and elk in the ninebark-timothy community in the clearcut than any other community.

\section{Seasonal Diet Preference}

Deer and elk showed definite seasonal trends in plants selected. Availability of preferred species appeared to be an important factor in determining diet composition.

During March, Sandberg bluegrass was the most heavily grazed grass species. It initiated growth prior to most other herbaceous species, providing tender leaf sprouts in late February. Other frequently used forages during this period were bluebunch wheatgrass, Idaho fescue (Festuca idahoensis), Kentucky bluegrass, and timothy. These species combined with Sandberg bluegrass accounted for over $90 \%$ of the big game diet during March.

From April through mid-May grasses continued to contribute a major portion of the diet. However, utilization of forbs had increased representing almost half of the forage consumed on the unlogged communities. Important forages consumed within the clearcut during April and mid-May were timothy, orchardgrass, blue wildrye, and Ross sedge (Carex rossii). Plant species utilized on adjacent unlogged communities were Sandberg bluegrass, common camas (Camassia quamash), Kellogg onion, and western 


\section{hawksbeard (Crepis occidentalis).}

From mid-May through June, forbs made up just over half of the diet with grasses still playing an important role. The two most important forage species during this period were timothy and western goatsbeard. Timothy was primarily utilized in the timothyorchardgrass community and western goatsbeard in the Kentucky bluegrass-goatsbeard community. Other forages utilized at this time were orchardgrass, smooth brome, blue wildrye, tall oatgrass, junegrass, tailcup lupine (Lupinus caudatus), prickly lettuce (Lactuca serriola), pale agoseris (Agoseris glauca), American adenocaulon, and snowberry.

In July and August, utilization was too light and scattered to be measured. When utilization was measured again in late fall, the majority of deer and elk were still at higher elevations probably due to the lack of snowfall.

\section{Conclusions and Management Implications}

From March through June, when deer and elk were in the study area, forage utilization occurred primarily on the nonforested plant communities. Bunchgrass and logged communities, which collectively occupied $57 \%$ of the area studied, provided approximately $90 \%$ of the forages in the big game diet. The presence and availability of palatable forages was much higher in these plant communities as compared to the forested communities. If these animals had not had access to high elevation range, forage utilization may have shifted into forested communities later in the summer as plants matured. Edgerton and Smith (1971) reported that during spring deer and elk fed mostly on grasslands and open forests in the Blue Mountains of northeastern Oregon. Availability of preferred forages has been shown to be an important parameter in influencing seasonal trends of habitat use by deer and elk (Edgerton 1971, 1972; Reynolds 1962, 1966). It is important for managers to consider not only the structural characteristics of a habitat but also the specific forage plants and their value to deer and elk. The seeded clearcut proved to be important as a forage source. Although the three communities in the forest clearcut accounted for approximately $31 \%$ of the area, these communities provided $66 \%$ of the big game diet. This was significantly higher than the same habitat types on the study area that had not been logged. Other researchers have also reported deer and elk use increased following logging (Reynolds 1962, 1966; Patton 1969; Edgerton 1972).

Pellet groups indicated that the bunchgrass and forested communities were either comparable to or more important than the clearcut communities. Seasonal distribution of deer and elk pellet groups within and across communities did not correlate with seasonal preferences of the various communities for forage use. In the past, various authors have used pellet groups as indicators of habitat use (McMain 1948; Julander 1958). However, this study and that of Leckenby (1968) indicated that pellet groups did not reliably estimate the value of various communities to deer and elk for forage use. The different responses of forage related parameters and pellet group distribution suggested that managers should consider indexes that incorporate both forage and other needs in evaluating suitability of habitats for deer and elk.

\section{Literature Cited}

Daubenmire, R. 1970. Steppe vegetation of Washington. Washington Agr. Exp. Sta. Pullman Tech. Bull. 62.131 p.

Daubenmire, R., and J.B. Daubenmire. 1968. Forest vegetation of eastern Washington and northern Idaho. Washington Agr. Exp. Sta. Pullman. Tech. Bull. 60. 104 p.

Edgerton, P.J. 1971. The affect of cattle and big game grazing on a ponderosa pine plantation. U.S.D.A. Pacific Northwest Forest and Range Exp. Sta. Res. Note PNW-172.

Edgerton, P.J. 1972. Big game use and habitat changes in a recently logged mixed conifer forest in northeastern Oregon. In: Proc. Annu. Conf. Western Ass. State Game and Fish Comm. 52:239-246.

Edgerton, P.J., and J.G. Smith. 1971. Seasonal forage use by deer and elk on the Starkey Experiment Range, Oregon. U.S.D.A. Pacific Northwest Forest and Range Exp. Sta. Res. Paper PNW-112. 12 p.

Hall, F.C. 1973. Plant communities of the Blue Mountains in eastern Oregon and southeastern Washington. U.S.D.A. Forest Serv. Pacific Northwest Reg. R6 Area Guide 3-1.62 p.

Julander, O. 1958. Techniques in studying competition between big game and livestock. J. Range Manage. 11:18-21.

Leckenby, D.A. 1968. Influences of plant communities on wintering mule deer. In: Proc. Annu. Conf. Western Ass. State Game and Fish Comm. 49:201-208.

McCain, R. 1948. A method for measuring deer range use. Trans. N. Amer. Wildl. Conf. 13:431-441.

Miller, R.F., and W.C. Krueger. 1976. Cattle use on summer foothill rangelands in northeastern Oregon. J. Range Manage. 29:367-371.

Neff, D.J. 1968. The pellet-group count technique for big game trend, census, and distribution: A review. J. Wildl. Manage. 32:597-614.

Patton, D.R. 1969. Deer and elk use of ponderosa pine forest in Arizona before and after harvest. U.S.D.A. Rocky Mountain Forest and Range Exp. Sta. Res. Note. RM-139. 7 p.

Pechanec, J.F., and G.D. Pickford. 1933a. A weight estimate method for the determination of range or pasture production. J. Amer. Soc. Agron. 29:894-904.

Pechanec, J.F., and G.D. Pickford. 1937b. A comparison of methods used in determining percentage utilization of range grasses. J. Agr. Res. 54:753-765.

Reynolds, H.G. 1962. Effect of logging on understory vegetation and deer use in ponderosa pine forest of Arizona. U.S.D.A. Rocky Mountain Forest and Range Exp. Sta. Res. Note RM-80. 7 p.

Reynolds, H.G. 1966. Use of openings in spruce-fir forests of Arizona by deer, elk, and cattle. U.S.D.A. Rocky Mountain Forest and Range Exp. Sta. Res. Note RM-66. 4 p.

Van Dyne, G.M., and H.F. Heady. 1965. Botanical composition of sheep and cattle diets on a mature annual range. Hilgardia 36:465-492.

Wilm, H.G., D.F. Costello, and G.E. Klipple. 1944. Estimating forage yield by the double sampling method. J. Amer. Soc. Agron. 36:194-203.

\section{Range Scientist}

Position: School of Forestry, University of Montana, has faculty position at assistant professor level, tenure track, academic year (9-months) appointment, 2/3 teaching and 1/3 research, opportunities for summer research support; Qualifications: At least one degree in range science/management, Ph.D. or equivalent degree in some aspect of range resources management; capable of conducting field instruction and research, effective in oral and written communication in English; Closing date: 6/1/81; Date available: Sept., 1981; Duties: Teach undergraduate and graduate courses in Range Resources Management Program, advise undergraduate and graduate students, develop research program in range; Application: Submit academic transcripts, complete resume, reprints, and letter of application including names and addresses of three persons from whom you have requested references to: Range Search Committee, School of Forestry, University of Montana, Missoula, MT 59812. EEO/AA employer. Women, minorities and handicapped are encouraged to apply. 